\title{
Distribution of Phosphorus Forms Depends on Compost Source Material
}

\author{
Marge Lanno ${ }^{1, *} \mathbb{C}$, Mait Kriipsalu ${ }^{2}$, Merrit Shanskiy ${ }^{1}$, Maidu Silm ${ }^{1}$ and Anu Kisand ${ }^{1}$ \\ 1 Institute of Agricultural and Environmental Sciences, Estonian University of Life Sciences, \\ 51006 Tartu, Estonia; merrit.shanskiy@emu.ee (M.S.); maidu.silm@emu.ee (M.S.); anu.kisand@emu.ee (A.K.) \\ 2 Institute of Forestry and Rural Engineering, Estonian University of Life Sciences, 51006 Tartu, Estonia; \\ mait.kriipsalu@emu.ee \\ * Correspondence: marge.lanno@emu.ee
}

check for

updates

Citation: Lanno, M.; Kriipsalu, M.; Shanskiy, M.; Silm, M.; Kisand, A. Distribution of Phosphorus Forms Depends on Compost Source

Material. Resources 2021, 10, 102. https://doi.org/10.3390/ resources 10100102

\section{Academic Editors:}

Konstadinos Abeliotis and Katia Lasaridi

\section{Received: 31 August 2021}

Accepted: 5 October 2021

Published: 8 October 2021

Publisher's Note: MDPI stays neutral with regard to jurisdictional claims in published maps and institutional affiliations.

Copyright: (C) 2021 by the authors. Licensee MDPI, Basel, Switzerland. This article is an open access article distributed under the terms and conditions of the Creative Commons Attribution (CC BY) license (https:// creativecommons.org/licenses/by/ $4.0 /)$.

\begin{abstract}
Composting is a sustainable method for recovering nutrients from various organic wastes, including food waste. Every input waste has different nutrient contents, in turn, suggesting that every compost has different fertilizer and/or soil improvement values. The phosphorus $(\mathrm{P})$ concentration and relative distribution of $\mathrm{P}$ forms is related to the original organic material. The relative distribution of $\mathrm{P}$ forms determines how readily plants can absorb $\mathrm{P}$ from the compost-amended soil. The aim of this study was to investigate the content and relative share of $P$ forms in composts made from fish waste, sewage sludge, green waste, and horse manure. Six forms of P (labile; bound to reducible metals; bound to non-reducible metals; bound to easily degradable organic material; and bound to calcium) were determined using sequential extraction method. The results indicated that fish waste compost had relatively high proportion of labile $\mathrm{P}$, suggesting good biological availability. In comparison, sewage sludge compost contained the highest overall $\mathrm{P}$ concentration per dry weight unit, while labile $\mathrm{P}$ constituted only $6 \%$ of summary of $\mathrm{P}$ forms. The results indicate that the evaluation of composts as alternative $\mathrm{P}$ sources in agriculture should rely on the relative distribution of $\mathrm{P}$ forms in the compost in addition to the typically recognized value of the total $\mathrm{P}$.
\end{abstract}

Keywords: organic fertilizer; sequential fractionation; fish waste; manure; sewage sludge; green waste; circular economy

\section{Introduction}

With the growing human population, the need for more sustainable agriculture and food production is increasingly essential. Likewise, as the population grows, the need for fertilizers increases. To ensure the higher crop yield, nitrogen $(\mathrm{N})$ and phosphorus $(\mathrm{P})$ fertilizers are widely used [1].

In general, $\mathrm{P}$ is added to the soil with chemical fertilizers. As phosphorite is mined from Earth's crust, our natural P resources become increasingly limited [2,3]. Similarly, significant quantities of $\mathrm{P}$ are being lost through the entire cycle of organic wastes. Furthermore, indiscriminate application of chemical fertilizers can exhaust the soil in the long term $[4,5]$. P run-off can result in environmental pollution and eutrophication in water bodies. To avoid increased $\mathrm{P}$ concentrations in streams and lakes, it is important that $\mathrm{P}$ added with fertilizers is assimilated by plants $[2,4,6]$.

Alternative $\mathrm{P}$ sources are needed to ensure sustainable crop production. To close the $\mathrm{P}$ cycle and promote food security and environmental integrity, the European Commission has announced the preparation of an Integrated Management Action Plan (INMAP) with the purpose of reducing the nutrient losses and stimulating the market for recovered nutrients [7]. Options for reducing $\mathrm{P}$ losses include the redistribution of $\mathrm{P}$ inputs, $\mathrm{P}$ recovery and recycling, and redefining $\mathrm{P}$ in the food web [8,9]. Organic materials that could potentially be recycled to recover $\mathrm{P}$ include manure, wastewater sludge, animal by-products, food waste, and other green wastes [10]. 
The composting of organic residues is one method of recycling organic materials. Composting can reduce the share of organic waste in landfills and reduce and stabilize the organic material [11]. As composting is an established method of processing organic wastes from various sources, requirements for safety, quality and labelling are established [12].

Compost is a natural fertilizer and/or soil improver that enhances soil chemical and physical parameters and provides essential nutrients, including P, for plant growth [13]. The method of composting can influence the $P$ forms in compost and, in turn, its availability for plants $[14,15]$. The $P$ concentration in compost depends on the input material as well as the composting process, time, and conditions. The availability of $\mathrm{P}$ for plants is determined not only by the amount of $\mathrm{P}$ in the compost but also by the $\mathrm{P}$ forms. As the nutrient concentration in compost depends on the original organic material, different composts contain different amount of $\mathrm{P}$ and different relative distribution of $\mathrm{P}$ forms [16,17].

This determines how well plants can absorb P from compost-amended soil and affects the marketing of compost products. Bioavailable P is needed for plant production. Plant roots mainly absorb inorganic $\mathrm{P}$ from the soil solution $[2,18,19]$. As the bioavailability is connected to solubility, water-soluble forms are the most bioavailable, followed by $\mathrm{P}$ adsorbed on manganese ( $\mathrm{Mn}$ ) and iron (Fe) oxides, organic $\mathrm{P}$ forms, and residual $\mathrm{P}$ forms [20]. Often, composts are characterized by their total $\mathrm{P}$ content, and no detailed identification of different $\mathrm{P}$ forms is required in compost quality manuals, fertilizer regulations, or national end-of-waste regulations $[12,21,22]$.

In the frames of the circular economy, bio-waste is an important resource for organic soil improvers and/or fertilizers. Compost, which is an organic fertilizer composed of different organic materials, has high nutritional value, including P. In general, the total P concentration must be made available according to the requirements for bio-waste management [12]. However, composts of different organic materials have distinct concentrations of total $\mathrm{P}$ and $\mathrm{P}$ forms $[16,23]$. We studied the relative share and distribution of $\mathrm{P}$ forms in fish waste composts compared with composts from other organic source materials. Based on the $\mathrm{P}$ content and relative share of different $\mathrm{P}$ forms, we show that composting low-value fish or fish-processing residues is a potentially feasible way to recover $P$ for agricultural use.

\section{Materials and Method}

\subsection{Preparations of Composts}

Six composts of different source material were used. Experimental composts were prepared from fish waste (FW1-FW3), horse manure (HM), green waste from municipal areas (GW), and sewage sludge (SS) from the regional municipal Wastewater Treatment Plant (WWTP) (Table 1). The WWTP uses $\mathrm{Fe}_{2}\left(\mathrm{SO}_{4}\right)_{3}$ salt PIX 113 (Kemira Oy, Helsinki, Finland) to chemically precipitate $\mathrm{P}$ from wastewater. All composts were processed in outdoor conditions in windrows and mixed mechanically with a windrow turner. All windrows were approximately $1.5 \mathrm{~m}$ high, $3 \mathrm{~m}$ wide, and $12 \mathrm{~m}$ long, and covered with semi-permeable geotextile KSV 200 (Compost Systems GmbH, Wels, Austria).

The optimal time-temperature regime depends on the input material. For waste containing animal by-products, such as fish waste and horse manure, the temperature must exceeded $70{ }^{\circ} \mathrm{C}$ for at least $1 \mathrm{~h}$, as required by the EU Commission regulation EU 142/2011 [24]. For composting biodegradable waste and sewage sludge, the temperature must exceed $55^{\circ} \mathrm{C}$ for 10 days, or $65^{\circ} \mathrm{C}$ for 3 days [22,25]. All composts were maintained in accordance with the requirements of these regulations. The duration of active composting was measured as a period when no further significant temperature increase occurred after the mixing of windrows. 
Table 1. Description of the composts. The share of organic material was calculated using the wet weight. The active composting time $(\mathrm{d})$ indicates the duration in days that composts were in outdoor windrows.

\begin{tabular}{|c|c|c|c|}
\hline Treatment Name & Source of Waste & Amendments & $\begin{array}{c}\text { Active Composting } \\
\text { Time (d) }\end{array}$ \\
\hline FW1 & Fish waste $(80 \%)$ & Un-shredded straw (20\%) & 185 \\
\hline FW2 & Fish waste $(57 \%)$ & Shredded straw (43\%), & 70 \\
\hline FW3 & Fish waste $(22 \%)$ & $\begin{array}{c}\text { Shredded straw }(22 \%) \text {, } \\
\text { peat }(22 \%) \text {, inoculum } \\
\text { from mature HM }(21 \%) \\
\text { and FW1 compost }(13 \%)\end{array}$ & 50 \\
\hline $\mathrm{HM}$ & Horse manure $(60 \%)$ & Straw $(40 \%)$ & 90 \\
\hline GW & Green waste $(100 \%)$ & None & $>180$ \\
\hline SS & Sewage sludge $(90 \%)$ & Un-shredded straw (10\%) & 120 \\
\hline
\end{tabular}

\subsection{Chemical Analysis}

Approximately $250 \mathrm{~g}$ of average samples were collected from each batch of readymade compost. One sample contained homogenized compost from three different locations $20-30 \mathrm{~cm}$ inside the windrow. The collected samples were dried at $105^{\circ} \mathrm{C}$ and ballmilled prior to analysis. Dry matter (DM) and loss of ignition were determined. The total $\mathrm{C}$ and $\mathrm{N}$ content was analyzed using a VarioMAX CNS analyzer (ELEMENTAR, Langenselbold Germany). Potassium (K), calcium $(\mathrm{Ca})$, and magnesium $(\mathrm{Mg})$ content was determined using the ammonium lactate (AL) method as described by Egner et al. [26]. The compost stability was determined by the four-day cumulative oxygen consumption via OxiTop manometric respirometry system (Xylem Analytics Germany Sales GmbH \& Co KG, Weilheim Germany according to the manufacturer's recommendations (Table 2).

Table 2. Characterization of composts.

\begin{tabular}{|c|c|c|c|c|c|c|c|c|c|}
\hline Treatment & $\mathbf{N}$ & $\mathrm{C}$ & $\mathrm{C} / \mathrm{N}$ & $\mathbf{K}$ & $\mathrm{Ca}$ & Mg & Dry Matter & Loss of Ignition & Stability \\
\hline \multicolumn{4}{|c|}{$(\%)$} & \multicolumn{3}{|c|}{$(\mathrm{mg} / 100 \mathrm{~g})$} & \multicolumn{2}{|r|}{$(\%)$} & $\left(\mathrm{mg} \mathrm{O}_{2} / \mathrm{g}\right)$ \\
\hline FW1 & 2.43 & 30.22 & 12.44 & 790.51 & 4471.04 & 703.31 & 53.80 & 75.40 & 3.00 \\
\hline FW2 & 2.75 & 33.04 & 12.01 & 1329.22 & 4625.55 & 664.00 & 47.94 & 85.78 & 11.20 \\
\hline FW3 & 2.73 & 35.66 & 13.06 & 1675.63 & 3166.32 & 680.48 & 34.79 & 87.05 & 10.40 \\
\hline HM & 2.47 & 30.99 & 12.55 & 2550.90 & 2986.40 & 649.17 & 37.83 & 79.67 & 3.20 \\
\hline GW & 0.60 & 13.35 & 22.25 & 552.08 & 6681.84 & 223.96 & 41.78 & 65.46 & 0.90 \\
\hline SS & 3.74 & 27.02 & 7.22 & 551.81 & 1169.69 & 517.71 & 44.16 & 61.34 & 6.70 \\
\hline
\end{tabular}

\subsection{Determination of $P$ Forms}

To assess different $P$ forms, a modification of the determined sequential extraction method was applied [27]. Using this method, six operationally defined P forms were determined ( $\mathrm{RP}$ - reactive $\mathrm{P}$; and $\mathrm{NRP}$ - non-reactive $\mathrm{P}$ ):

- $\quad \mathrm{NH}_{4} \mathrm{Cl}-\mathrm{RP}$ - “Labile $\mathrm{P}$ ”, immediately available $\mathrm{P}$, which is loosely bound;

- $\quad$ BD-RP P- “Fe-P”, bound to reducible metals (Fe, Mn);

- $\mathrm{NaOH}-\mathrm{RP}$ - “Al-P”, phosphates absorbed to metals $\left(\mathrm{Al}, \mathrm{M}_{\mathrm{x}} \mathrm{O}_{\mathrm{y}}\right)$;

- $\mathrm{NaOH}-\mathrm{NRP}$ - “Org-P”, bound to organic material and colloids, determined as difference between soluble reactive $\mathrm{P}$ and total $\mathrm{P}$ in $\mathrm{NaOH}$ extract; and

- $\mathrm{HCl}-\mathrm{RP}$ — “Ca-P”, bound to calcium (Ca).

From the collected samples, $0.025 \mathrm{~g}$ of dried material was analyzed in three replicates (Figure 1). For extraction, $10 \mathrm{~mL}$ of $0.1 \mathrm{M} \mathrm{NH}_{4} \mathrm{Cl}$ was added to the compost sample in $15 \mathrm{~mL}$ Falcon centrifugation tubes and rotated using a Hettich Universal 320 centrifuge (Andreas Hettich GmbH \& Co. KG, Germany) for $2 \mathrm{~h}$. After $10 \mathrm{~min}$ of centrifugation at $4000 \mathrm{rpm}$, the supernatant was collected for $2 \mathrm{~h}$. After $10 \mathrm{~min}$ of centrifugation at $4000 \mathrm{rpm}$, 
the supernatant was collected for further analysis. We added $10 \mathrm{~mL}$ of $0.1 \mathrm{M} \mathrm{NaOH}$ to the pellet for a repeated extraction step.

In a third step, $10 \mathrm{~mL}$ of $0.11 \mathrm{M}$ bicarbonate/dithionite (BD) solution was added to the pellet and incubated for $1 \mathrm{~h}$ at $40^{\circ} \mathrm{C}$, followed by centrifugation, supernatant removal, and rinsing of the remaining sediment pellet with another $5 \mathrm{~mL}$ of $\mathrm{BD}$ solution. The latter was added to the previously decanted $10 \mathrm{~mL}$ of $\mathrm{BD}$ extract after centrifugation. In the next step, $10 \mathrm{~mL}$ of $0.1 \mathrm{M} \mathrm{NaOH}$ was added to the sediment pellet, and the tubes were rotated for $16 \mathrm{~h}$, followed by centrifugation and supernatant collection. In the final extraction step, $10 \mathrm{~mL}$ of $0.5 \mathrm{M} \mathrm{HCl}$ was added to the pellet, and the tubes were rotated for $24 \mathrm{~h}$.

The soluble reactive $\mathrm{P}(\mathrm{SRP})$ in each extract was determined using a spectrophotometer Shimadzu UV-1800 (Shimadzu Corporation, Japan) via the molybdenum blue method [28]. The total $\mathrm{P}$ concentration in the $\mathrm{NaOH}$ extract was also determined as SRP after persulphate digestion of the $\mathrm{NaOH}$ extract at $121{ }^{\circ} \mathrm{C}$ for $1 \mathrm{~h}$. Specifically, $2 \mathrm{~mL}$ of $5 \% \mathrm{~K}_{2} \mathrm{~S}_{2} \mathrm{O}_{8}$ was added to $10 \mathrm{~mL}$ of solution containing $2 \mathrm{~mL}$ of $\mathrm{NaOH}$ extract, $0.5 \mathrm{~mL} 0.5 \mathrm{M} \mathrm{HCl}$ and $7.6 \mathrm{~mL}$ distilled water and autoclaved. If needed, the solution was diluted prior absorbance measurement. The NRP concentration in the $\mathrm{NaOH}$ extract was calculated as the difference between the total $\mathrm{P}$ and SRP concentration in the extract.

$\mathrm{NaOH}$ extract from sewage sludge and fish compost samples contained white haze after persulphate digestion. To remove the haze, the solution was filtered through a $0.45 \mu \mathrm{m}$ pore size syringe filter Millex-LCR Hydrophilic PTFE (Merck KGaA, Germany) before adding a molybdenum reagent. Based on the concentration of the analyzed $\mathrm{P}$ forms, the summary of determined P forms (SumP) was calculated.

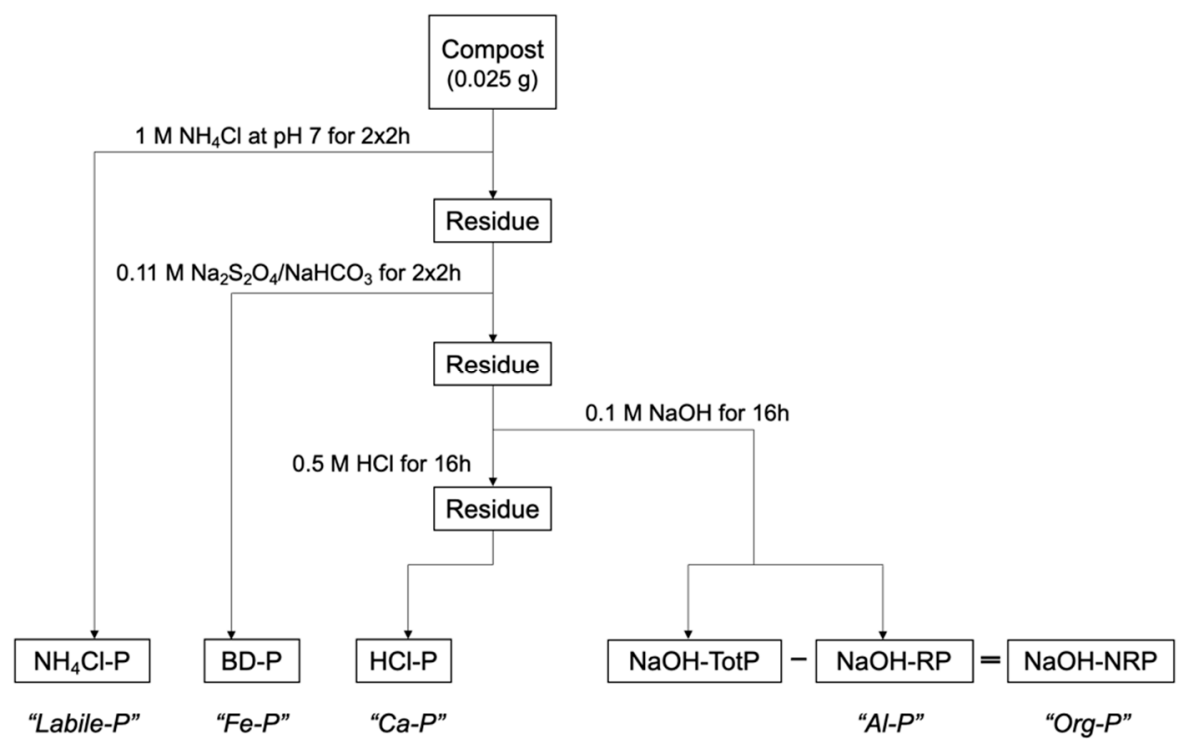

Figure 1. Phosphorus $(\mathrm{P})$ fractionation scheme. Labile-P is water soluble and loosely bound $\mathrm{P}$; Fe-P is iron bound P; Ca-P is calcium bound P; Al-P is aluminum bound P; and Org-P is P bound to organic material.

\subsection{Statistical Analysis}

Statistical analysis was performed in R [29]. The Shapiro-Wilk test was used to confirm normality. One-way ANOVA was used to study the effect of compost type on different $P$ forms. The Tukey HSD post-hoc test, using the package "agricolae", was performed for pairwise comparisons [30].

\section{Results}

Six composts with different organic material each contained a different SumP (Figure 2). SumP varied, on average, from $2.73 \mathrm{~g} \mathrm{P} / \mathrm{kg}$ dry weight (DW) in the GW compost to $16.27 \mathrm{~g} \mathrm{P} / \mathrm{kg}$ DW in the SS compost (Table 3). FW composts ranged from $10.40 \mathrm{~g} \mathrm{P} / \mathrm{kg}$ DW 
in the FW3 compost to $13.53 \mathrm{~g} \mathrm{P} / \mathrm{kg}$ DW in the FW2 compost. Statistically, FW 1-3 contained similar SumP to both the SS and HM composts.

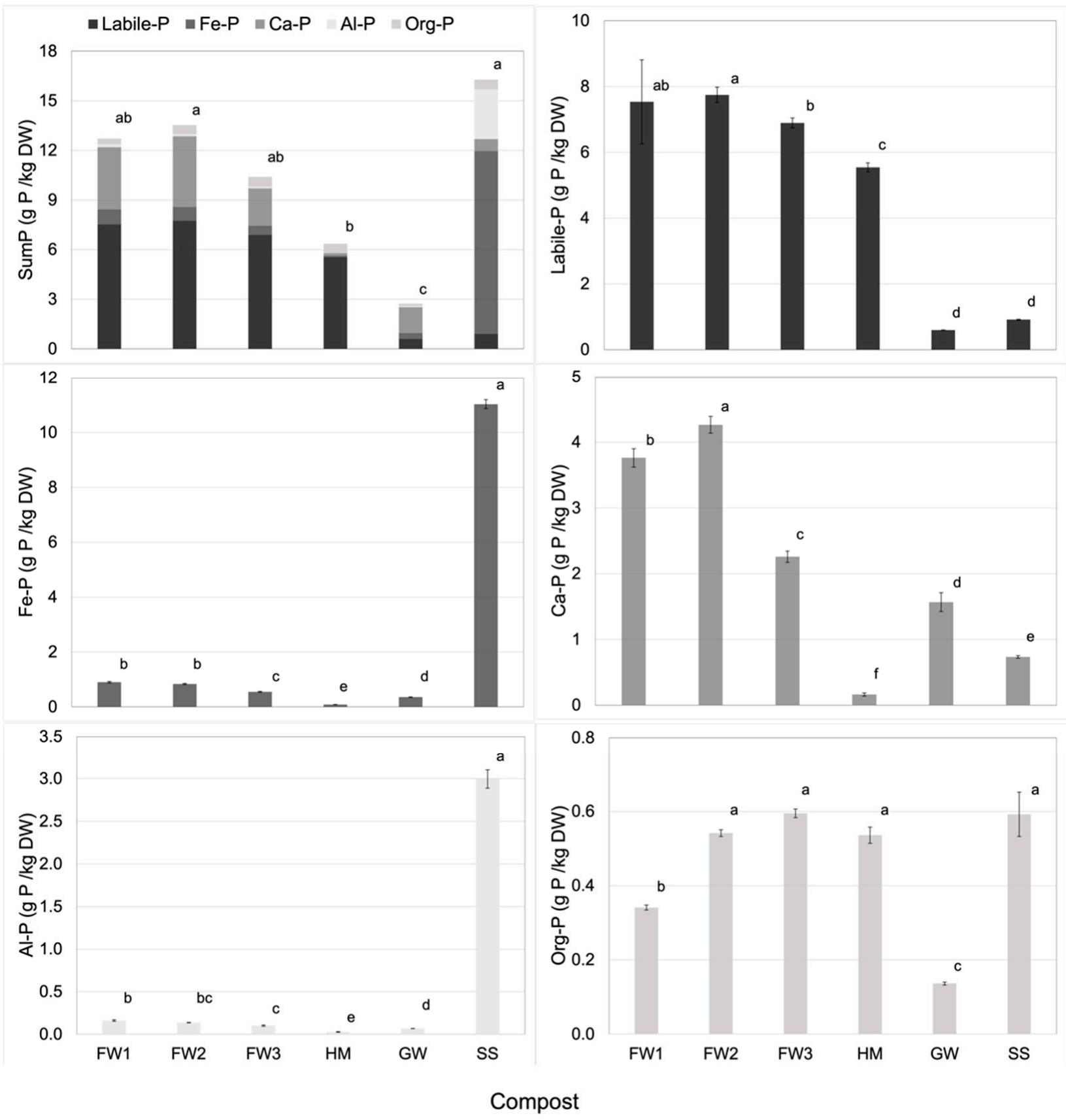

Figure 2. Concentrations of different phosphorus $(\mathrm{P})$ forms ( $\mathrm{g} / \mathrm{kg} \mathrm{DW})$. Labile-P is water soluble and loosely bound $\mathrm{P}$; Fe-P is iron bound P; Ca-P is calcium bound P; Al-P is aluminum bound P; and Org-P is P bound to organic material. Different letters indicate statistically significant differences between groups, according to the Tukey HSD test $(\alpha=0.05)$. 
Table 3. Average phosphorus (P) concentrations ( $\mathrm{g} \mathrm{P} / \mathrm{kg}$ DW). Labile-P is water soluble and loosely bound P; Fe-P is iron bound P; Ca-P is calcium bound P; Al-P is aluminum bound P; and Org-P is $\mathrm{P}$ bound to organic material.

\begin{tabular}{ccccccc}
\hline Compost & Labile-P & Fe-P & Ca-P & Al-P & Org-P & SumP \\
\hline FW1 & 7.53 & 0.90 & 3.76 & 0.16 & 0.34 & 12.70 \\
FW2 & 7.75 & 0.83 & 4.27 & 0.14 & 0.54 & 13.53 \\
FW3 & 6.90 & 0.55 & 2.26 & 0.10 & 0.59 & 10.40 \\
HM & 5.55 & 0.09 & 0.16 & 0.03 & 0.54 & 6.36 \\
GW & 0.60 & 0.35 & 1.57 & 0.07 & 0.14 & 2.73 \\
SS & 0.92 & 11.03 & 0.74 & 3.00 & 0.59 & 16.27 \\
\hline
\end{tabular}

In addition to SumP, the composts varied in concentration of $\mathrm{P}$ forms. Concentration of labile-P, the most bioavailable $\mathrm{P}$ form, was highest in the FW2 compost $(7.75 \mathrm{~g} \mathrm{P} / \mathrm{kg} \mathrm{DW})$, followed by FW1 (7.53 g P/kg DW) and FW3 composts (6.90 g P/ $\mathrm{kg} \mathrm{DW).} \mathrm{The} \mathrm{lowest}$ concentration of labile-P was in the GW compost $(0.92 \mathrm{~g} \mathrm{P} / \mathrm{kg}$ DW). While the SS compost had the highest SumP, its concentration of labile-P was similar to that of the GW compost.

Compared to other composts, the SS compost contained at least 12-times higher concentration of Fe-P (11.03 g P / kg DW). Similar results were observed for Al-P, of which the concentration in most composts did not exceed $0.16 \mathrm{~g} \mathrm{P} / \mathrm{kg}$ DW; while in the SS compost, the Al-P concentration was $3.00 \mathrm{~g} \mathrm{P} / \mathrm{kg}$ DW. This is presumably related to the sewage sludge from external small-size WWTPs, where $\mathrm{Al}_{2}\left(\mathrm{SO}_{4}\right)_{3}$ is used for wastewater precipitation.

The FW compost contained a remarkable amount of apatite, likely related to the $\mathrm{Ca}-\mathrm{P}$ from the fish bones. The highest concentration of Ca-P was in the FW2 compost (4.27 g P/kg DW), followed by FW1 (3.76 g P/kg DW) and FW3 (2.26 g P/kg DW). As green waste is collected from the area, where limestone bedrock is close to the surface, the GW compost contained a considerable amount of Ca-P $(1.57 \mathrm{~g} \mathrm{P} / \mathrm{kg}$ DW). The lowest concentration of Ca-P was observed in the HM compost ( $0.16 \mathrm{~g} \mathrm{P} / \mathrm{kg} \mathrm{DW})$.

The FW2, FW3, HM, and SS composts contained similar amounts of Org-P, (ranging from $0.54 \mathrm{~g} \mathrm{P} / \mathrm{kg}$ DW in the HM compost to $0.59 \mathrm{~g} \mathrm{P} / \mathrm{kg}$ DW in the FW3 compost).

The relative share of $\mathrm{P}$ forms varied according to the organic material of the composts. The highest relative share of labile-P was in the HM compost at $87 \%$ of SumP (Figure 3). While the FW composts contained the highest concentration of labile-P per $\mathrm{P} / \mathrm{kg} \mathrm{DW}$, the relative share of labile-P varied in composts FW1-3 (57-66\%). The SS compost with the highest SumP contained the lowest share of labile-P (6\%).

Generally, the relative share of Fe-P and Al-P in various composts were relatively low ( $\mathrm{Fe}-\mathrm{P}<13 \%$ and $\mathrm{Al}-\mathrm{P}<3 \%$ ), except in the SS compost, where the share of $\mathrm{Fe}-\mathrm{P}$ was $68 \%$, and Al-P was $18 \%$. The highest share of Ca-P was in the GW compost (57\%), followed by FW composts (up to $32 \%$ ). The SS compost contained 5\%, and the HM compost contained $3 \%$ of Ca-P. The share of Org-P remained $<10 \%$ in every compost. 


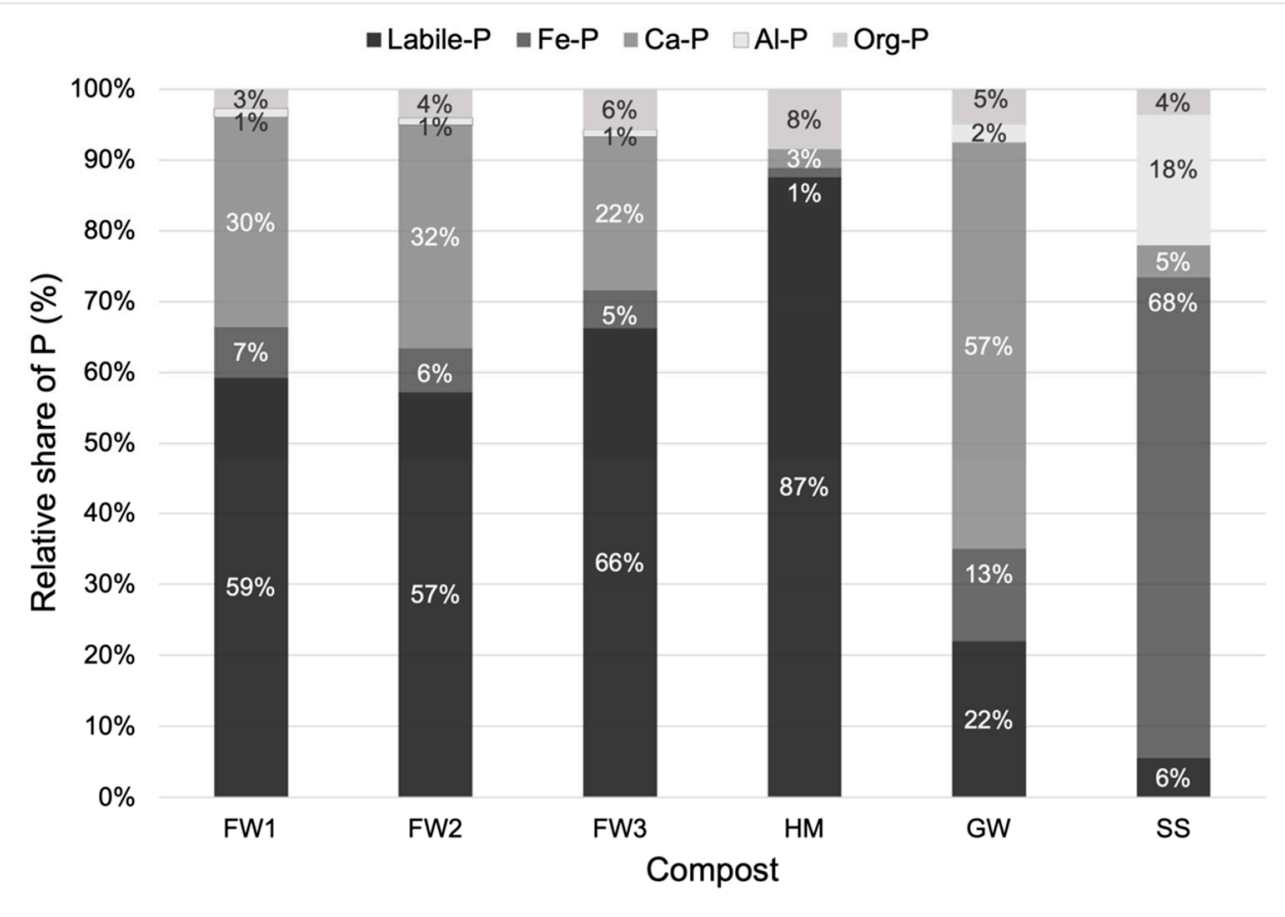

Figure 3. Relative share of phosphorus (P) forms (\%). Labile-P is water soluble and loosely bound P; Fe-P is iron bound P; Ca-P is calcium bound P; Al-P is aluminum bound P; and Org-P is P bound to organic material.

\section{Discussion}

Ecologically significant $\mathrm{P}$ forms of composts were determined in our study. The difference between SumP and total P is referred to as residual P [31]. Since residual P is considered to be a stable $\mathrm{P}$ form that does not add to the pool of bioavailable $\mathrm{P}$, it is a less significant $\mathrm{P}$ form from the aspect of fertilization $[32,33]$. In the present study, the compost with the greatest SumP was the SS compost, followed by FW composts, the HM compost, and finally the GW compost.

In the present study, the summarized content of $\mathrm{P}$ forms in FW composts was relatively high. The total $\mathrm{P}$ content of $\mathrm{FW}$ composts in other studies were reported as $2.6 \mathrm{~g} \mathrm{P} / \mathrm{kg} \mathrm{DW} \mathrm{[34]} \mathrm{and} 6 \mathrm{~g} \mathrm{P} / \mathrm{kg}$ DW [35]. A compost's P concentration depends on both the relative share of bulking material and the composition of fish waste. The total $\mathrm{P}$ concentration in fish and fish waste has been reported to fall into a range of $1-3.5 \%$ of dry weight (respectively, 10-35 g P/kg DW) [36,37]. Fish bones, which contain large proportions of hydroxyapatite, can have P concentrations above $120 \mathrm{~g} \mathrm{P} / \mathrm{kg}$ DW $[36,38]$. Straw, pine bark, sawdust, seaweed, and peat are examples of bulking agents used in fish composts $[34,35]$. In the present study, straw and peat were the main bulking materials for FW composts, whereas fish waste constituted up to $80 \%$ (on a wet weight bases) of the initial contents of the FW composts.

Composts with different organic materials have different concentrations of $P$ forms $[16,23]$. Fish waste is known to be a good source of $P$ for plant growth [34,36]. In the present study, $7.75 \mathrm{~g} \mathrm{P} / \mathrm{kg}$ DW in the FW2 compost, and over $50 \%$ of P in all FW composts, was present in a labile, potentially bioavailable form. FW composts also contained relatively high shares of Ca-P, most likely due to the high presence of hydroxyapatite in fish bones and scales. Ca-P is regarded as a stable $\mathrm{P}$ form $[19,39]$. In another study on fish bones, easily-extractable $\mathrm{P}$ was shown to be $4.21 \mathrm{~g} \mathrm{P} / \mathrm{kg}$ DW, while the total P in fish bones was $120 \mathrm{~g} \mathrm{P} / \mathrm{kg} \mathrm{DM} \mathrm{[40].}$

Although FW composts contained the highest concentration of labile-P per DW, the relative share of labile-P was highest in the HM compost. As FW and HM composts have high ratios of readily-bioavailable $\mathrm{P}$, they have a high potential to partly replace mineral $\mathrm{P}$ fertilizers and, thus, reduce the dependency on $\mathrm{P}$ fertilizers derived from phosphorite. 
Water soluble P is bioavailable for plants; however, in the case of overuse, it has a high potential to be easily leached from the soil. Therefore, knowledge regarding the distribution of $\mathrm{P}$ forms in composts could be valuable when evaluating composts as sources of $\mathrm{P}$ fertilizers $[23,39]$.

To reduce the leaching of $\mathrm{P}$ from soils, thereby reducing $\mathrm{P}$ pollution in water bodies, cocomposting wastes with higher proportions of bioavailable $\mathrm{P}$ together with the wastes with low concentration of bioavailable P should be considered [16]. Thus, it may be beneficial to co-compost fish waste and green wastes. It has been shown that green waste low in sumP and labile-P concentrations represents a suitable material to compost in combination with other organic materials to enhance the degradation of organic matter, humification, and nutrient content [41].

Studies of $\mathrm{P}$ forms in organic source materials have revealed low portions of labile-P but high total $\mathrm{P}$ in sewage sludge, which is in accordance with the present study. Sewage sludge total P content was reported to be higher than $30 \mathrm{~g} \mathrm{P} / \mathrm{kg} \mathrm{DM}$; however, after mixing with soil, only $1-2 \%$ of the total $\mathrm{P}$ was in labile form [31]. In the present study, the SS compost contained the highest overall P concentration per DW; however, a low concentration of it was in a potentially bioavailable form. Instead, the majority of it was bound to Fe and $\mathrm{Al}$ compounds. Nevertheless, depending on the environmental conditions, $\mathrm{P}$ added to soil can alter the composition of $\mathrm{P}$ forms and its bioavailability for plants $[19,39]$. Related to the dynamic equilibrium between $\mathrm{P}$ pools, $\mathrm{P}$ is continuously released from other fractions to the bioavailable form [19].

It has been suggested that $\mathrm{P}$ bound to $\mathrm{Al}$ and Fe may become mobilized when labile-P pools are depleted from the soil [42]. It was shown that, depending on the soil pH, Al-P can have higher bioavailability than Fe-P or Ca-P, and therefore Al-P is considered as a potentially bioavailable form $[39,43]$. Fe-P is a highly stable $\mathrm{P}$ form in oxic conditions; however, it can become unstable at certain times of the year, when anaerobic soil conditions occur or when lower $\mathrm{pH}$ conditions catalyze Fe reduction, thus, resulting in the dissolution of both Fe and Fe-P [39,43]. As the SS compost in the present study contained a relatively high concentration of $\mathrm{P}$ in fixed form (18\% Al-P and $68 \% \mathrm{Fe}-\mathrm{P})$, we recommend application of biological rather than chemical P removal in WWTPs when considering further use of sewage sludge as fertilizer.

SS composts are subject to national wastewater regulations and may exceed the limit values of heavy metals or other safety and quality indicators. Therefore, the requirements and limits for the use of SS composts have been stated [44]. However, the potential of sewage sludge for agricultural use has been discussed, and, with potentially high bioavailable $\mathrm{P}$ content, it may represent an alternative to chemical fertilizer for crops of moderate demand [45-47].

As composts vary in nutrient content, it may be beneficial to combine both organic and mineral fertilizers, as their integration has been reported to improve P solubilization, as well as minimize P precipitation in soil and, thus, has helped in increasing the P availability for crops [48].

\section{Conclusions}

Composts containing different organic source materials-fish waste, horse manure, green waste, and sewage sludge-showed significant differences in the content and relative share of phosphorus forms.

Green waste (GW; from leaves, branches, and plant residues) and horse manure (HM) composts are widely used. However, GW compost is low in P content, and a relatively low percent of it is in labile-P form. HM compost, which is highly valued in agriculture, is rich in $\mathrm{P}$ content, and the majority of $\mathrm{P}$ was in labile-P form. This should be considered when calculating the compost application rate.

Sewage sludge (SS) compost contained the highest concentration of P content. However, the majority of it was bound to Fe or Al, reducing the availability for plant uptake. $\mathrm{P}$ in sewage sludge is from biological or chemical P-removal from wastewater. There- 
fore, the $\mathrm{P}$ concentration in sewage sludge is related to the $\mathrm{P}$ removal efficiency during wastewater treatment, as well as whether the P removal is biological or Fe- or Al-based. To ensure better $\mathrm{P}$ bioavailability for plants, we recommend biological $\mathrm{P}$ removal during wastewater treatment.

Fish waste (FW) compost is not widely used although it is very rich in P content, and a relatively high concentration of this is in labile-P form. Therefore, it could be suitable for crops that require available $\mathrm{P}$ immediately. Food waste that has equal compost qualities as fish waste should be re-assessed as a compost source and returned to agricultural production accordingly.

Composts represent valuable sources of recovered nutrients, including $\mathrm{P}$, and should be considered as an alternative to mineral $P$ fertilization, allowing recycling of the $P$ present in organic wastes back into soils. The evaluation of different composts as a source of $\mathrm{P}$ fertilizer should consider the relative share and potential bioavailability of different $P$ forms present in the composts.

Author Contributions: Conceptualization, M.L., M.K., M.S. (Merrit Shanskiy) and A.K.; methodology, A.K.; validation, A.K.; formal analysis, M.L.; investigation, M.L. and A.K.; resources, M.K., M.S. (Maidu Silm) and A.K.; data curation, A.K.; writing-original draft preparation, M.L. and A.K.; Writing-review and editing, M.K., M.S. (Merrit Shanskiy), M.S. (Maidu Silm) and A.K. visualization, M.L. and A.K.; supervision, M.K., M.S. (Merrit Shanskiy) and A.K.; project administration, M.K. and M.S. (Maidu Silm); funding acquisition, M.K. and M.S. (Maidu Silm). All authors have read and agreed to the published version of the manuscript.

Funding: This research was funded by “European Maritime and Fisheries Fund 2014-2020" project number 811017780003; Estonian Environmental Investment Centre project nr 15238; Estonian University of Life Sciences projects PM180259PKKH and PM180261MIMV; and European Union's European Regional Development Fund (Estonian University of Life Sciences ASTRA project "Value-chain based bioeconomy").

Institutional Review Board Statement: Not applicable.

Informed Consent Statement: Not applicable.

Data Availability Statement: Data is available upon request from corresponding author M.L.

Acknowledgments: We would like to thank Jordi Escuer for guidance regarding the statistical analysis and Jonathan Willow for language editing.

Conflicts of Interest: The authors declare no conflict of interest.

\section{References}

1. Bajwa, A.A.; Khan, M.J.; Bhowmik, P.C.; Walsh, M.; Chauhan, B.S. Sustainable Weed Management. In Innovations in Sustainable Agriculture; Farooq, M., Pisante, M., Eds.; Springer: Cham, Switzerland, 2019; ISBN 978-3-030-23168-2. [CrossRef]

2. Holford, I.C.R. Soil phosphorus: Its measurement, and its uptake by plants. Soil Res. 1997, 35, 227. [CrossRef]

3. Driver, J.; Lijmbach, D.; Steen, I. Why Recover Phosphorus for Recycling, and How? Environ. Technol. 1999, 20, 651-662. [CrossRef]

4. Savci, S. Investigation of Effect of Chemical Fertilizers on Environment. APCBEE Procedia 2012, 1, 287-292. [CrossRef]

5. Massah, J.; Azadegan, B. Effect of Chemical Fertilizers on Soil Compaction and Degradation. Agric. Mech. Asia, Afr. Lat. Am. 2016, $47,44-50$.

6. Rittmann, B.E.; Mayer, B.; Westerhoff, P.; Edwards, M. Capturing the lost phosphorus. Chemosphere 2011, 84, 846-853. [CrossRef] [PubMed]

7. European Comission. Communication from the Commission to the European Parliament, the Council, the European Economic and Social Committee and the Committee of the Regions. A New Circular Economy Action Plan. For a Cleaner and More Competitive Europe. COM/2020/98 final. European Comission: Brussels, Belgium, 2020; p. 20. Available online: https: / / eur-lex.europa.eu/legal-content/EN/TXT/?qid=1583933814386\&uri=COM:2020:98:FIN (accessed on 7 October 2021).

8. Withers, P.J.A.; Van Dijk, K.C.; Neset, T.-S.S.; Nesme, T.; Oenema, O.; Rubæk, G.H.; Schoumans, O.F.; Smit, B.; Pellerin, S. Stewardship to tackle global phosphorus inefficiency: The case of Europe. AMBIO 2015, 44, 193-206. [CrossRef]

9. Powers, S.M.; Chowdhury, R.; Macdonald, G.K.; Metson, G.S.; Beusen, A.H.W.; Bouwman, A.F.; Hampton, S.E.; Mayer, B.K.; McCrackin, M.L.; Vaccari, D.A. Global Opportunities to Increase Agricultural Independence Through Phosphorus Recycling. Earth's Futur. 2019, 7, 370-383. [CrossRef] 
10. Mayer, B.K.; Baker, L.A.; Boyer, T.H.; Drechsel, P.; Gifford, J.; Hanjra, M.A.; Parameswaran, P.; Stoltzfus, J.; Westerhoff, P.; Rittmann, B.E. Total Value of Phosphorus Recovery. Environ. Sci. Technol. 2016, 50, 6606-6620. [CrossRef]

11. European Environment Agency. Bio-Waste_Mainly Food and Garden Waste-Is a Key Waste Stream with a High Potential for Contributing to a More Circular Economy. This Report Provides an Overview of Bio-Waste Generation, Prevention, Collection, and Treatment in Europe; European Environment Agency: Copenhagen, Denmark, 2020. [CrossRef]

12. European Parliament. Regulation (EU) 2019/1009 of the European Parliament and of the Council of 5 June 2019 Laying down Rules on the Making Available on the Market of EU Fertilising Products and Amending Regulations (EC) No 1069/2009 and (EC) No 1107/2009 and Repealing Regulation (EC) No 2003/2003; EUR-Lex: Luxembourg, Luxembourg, 2019. Available online: http:/ / data.europa.eu/eli/ $\mathrm{reg} / 2019 / 1009 /$ oj (accessed on 7 October 2021).

13. Sánchez, J.; Ospina, D.A.; Montoya, S. Compost supplementation with nutrients and microorganisms in composting process. Waste Manag. 2017, 69, 136-153. [CrossRef]

14. Busato, J.G.; Lima, L.S.; Aguiar, N.O.; Canellas, L.P.; Olivares, F.L. Changes in labile phosphorus forms during maturation of vermicompost enriched with phosphorus-solubilizing and diazotrophic bacteria. Bioresour. Technol. 2012, 110, 390-395. [CrossRef]

15. Ngo, P.-T.; Rumpel, C.; Ngo, Q.-A.; Alexis, M.; Vargas, G.V.; Gil, M.D.L.L.M.; Dang, D.-K.; Jouquet, P. Biological and chemical reactivity and phosphorus forms of buffalo manure compost, vermicompost and their mixture with biochar. Bioresour. Technol. 2013, 148, 401-407. [CrossRef]

16. Wei, Y.; Zhao, Y.; Xi, B.; Wei, Z.; Li, X.; Cao, Z. Changes in phosphorus fractions during organic wastes composting from different sources. Bioresour. Technol. 2015, 189, 349-356. [CrossRef]

17. Gagnon, B.; Demers, I.; Ziadi, N.; Chantigny, M.H.; Parent, L.; Forge, T.A.; Larney, F.J.; Buckley, K.E. Forms of phosphorus in composts and in compost-amended soils following incubation. Can. J. Soil Sci. 2012, 92, 711-721. [CrossRef]

18. Shen, J.; Yuan, L.; Zhang, J.; Li, H.; Bai, Z.; Chen, X.; Zhang, W.; Zhang, F. Phosphorus Dynamics: From Soil to Plant. Plant Physiol. 2011, 156, 997-1005. [CrossRef]

19. Naidu, R.; Bolan, N.S.; Megharaj, M.; Juhasz, A.L.; Gupta, S.K.; Clothier, B.E.; Schulin, R. Chemical Bioavailability in Terrestrial Environments. In Developments in Soil Science; Elsevier: Amsterdam, The Netherlands, 2008; ISBN 978-0-444-52169-9.

20. Jakubus, M. Estimation of phosphorus bioavailability from composted organic wastes. Chem. Speciat. Bioavailab. 2016, 28, 189-198. [CrossRef]

21. Siebert, S.; Auweele, W.V. ECN-Qas European Quality Assurance Scheme for Compost and Digestate; European Compost Network ECN e.V.: Bochum, Germany, 2014; ISBN 978-3-00-047599-3.

22. Regulation of the Republic of Estonia. Biolagunevatest Jäätmetest Komposti Tootmise Nõuded. RT I, 18.12.2020, 23; Keskkonnaminister: Tallinn, Estonia, 2021.

23. Sharpley, A.; Moyer, B. Phosphorus Forms in Manure and Compost and Their Release during Simulated Rainfall. J. Environ. Qual. 2000, 29, 1462-1469. [CrossRef]

24. European Parliament. Commission Regulation (EU) No 142/2011 of 25 February 2011 Implementing Regulation (EC) No 1069/2009 of the European Parliament and of the Council Laying down Health Rules as Regards Animal By-Products and Derived Products Not Intended for Human Consumption and Implementing Council Directive 97/78/EC as Regards Certain Samples and Items Exempt from Veterinary Checks at the Border under That Directive (Text with EEA Relevance); EUR-Lex: Luxembourg, Luxembourg, 2011. Available online: http:/ / data.europa.eu/eli/reg/2011/142/oj (accessed on 7 October 2021).

25. Regulation of the Republic of Estonia. Haljastuses, Rekultiveerimisel Ja Põllumajanduses Kasutatava Reoveesette Kvaliteedi Piirväärtused Ning Kasutamise Nõuded. RT I, 06.08.2019, 7; Keskkonnaminister: Tallinn, Estonia, 2019.

26. Egner, H.; Riehm, H.; Domingo, W.R. Investigations on the Chemical Soil Analysis as a Basis for Assessing the Soil Nutrient Status. II: Chemical Extraction Methods for Phosphorus and Potassium Determination. K. Lantbr. Ann. 1960, $26,199-215$.

27. Rydin, E. Potentially mobile phosphorus in Lake Erken sediment. Water Res. 2000, 34, 2037-2042. [CrossRef]

28. Murphy, J.; Riley, J. A modified single solution method for the determination of phosphate in natural waters. Anal. Chim. Acta 1962, 27, 31-36. [CrossRef]

29. R Core Team. R: A Language and Environment for Statistical Computing; R Foundation for Statistical Computing: Vienna, Austria, 2020.

30. Mendiburu, F.D. Agricolae: Statistical Procedures for Agricultural Research. R Package Version 1.2-3. 2015.

31. Rydin, E.; Otabbong, E. Potential Release of Phosphorus from Soil Mixed with Sewage Sludge. J. Environ. Qual. 1997, 26, 529-534. [CrossRef]

32. Blake, L.; Johnston, A.; Poulton, P.; Goulding, K. Changes in soil phosphorus fractions following positive and negative phosphorus balances for long periods. Plant Soil 2003, 254, 245-261. [CrossRef]

33. Carter, M.R.; Gregorich, E.G. Soil Sampling and Methods of Analysis; CRC Press: Boca Raton, FL, USA, 2007.

34. Radziemska, M.; Vaverková, M.D.; Adamcová, D.; Brtnický, M.; Mazur, Z. Valorization of Fish Waste Compost as a Fertilizer for Agricultural Use. Waste Biomass-Valorization 2019, 10, 2537-2545. [CrossRef]

35. Illera-Vives, M.; Labandeira, S.S.; Loureiro, L.I.; López-Mosquera, M.E. Agronomic assessment of a compost consisting of seaweed and fish waste as an organic fertilizer for organic potato crops. Environ. Boil. Fishes 2017, 29, 1663-1671. [CrossRef]

36. Ahuja, I.; Dauksas, E.; Remme, J.F.; Richardsen, R.; Løes, A.-K. Fish and fish waste-based fertilizers in organic farming-With status in Norway: A review. Waste Manag. 2020, 115, 95-112. [CrossRef] [PubMed] 
37. Dantas, M.C.; Attayde, J.L. Nitrogen and phosphorus content of some temperate and tropical freshwater fishes. J. Fish Biol. 2007, 70, 100-108. [CrossRef]

38. Ramadhani, S.; Iswanto, B.; Purwaningrum, P. Waste utilization of red snapper (Lutjanus sp.) fish bone to improve phosphorus contents in compost. IOP Conf. Series: Earth Environ. Sci. 2018, 106, 12091. [CrossRef]

39. Yan, X.; Yang, W.; Chen, X.; Wang, M.; Wang, W.; Ye, D.; Wu, L. Soil Phosphorus Pools, Bioavailability and Environmental Risk in Response to the Phosphorus Supply in the Red Soil of Southern China. Int. J. Environ. Res. Public Health 2020, 17, 7384. [CrossRef]

40. Ahuja, I.; Løes, A.K. Effect of Fish Bones and Algae Fibre as Fertilisers for Ryegrass; NORSØK: Tingvoll, Norway, $2019 ;$ pp. 1-64.

41. Zhang, L.; Sun, X. Addition of fish pond sediment and rock phosphate enhances the composting of green waste. Bioresour. Technol. 2017, 233, 116-126. [CrossRef]

42. Saleque, M.A.; Naher, U.A.; Islam, A.; Pathan, A.B.M.B.U.; Hossain, A.T.M.S.; Meisner, C.A. Inorganic and Organic Phosphorus Fertilizer Effects on the Phosphorus Fractionation in Wetland Rice Soils. Soil Sci. Soc. Am. J. 2004, 68, 1635-1644. [CrossRef]

43. Syers, J.K.; Johnston, A.E.; Curtin, D. Efficiency of Soil and Fertilizer Phosphorus Use: Reconciling Changing Concepts of Soil Phosphorus Behaviour with Agronomic Information; FAO Fertilizer and Plant Nutrition Bulletin; Food and Agriculture Organization of the United Nations: Rome, Italy, 2008; ISBN 978-92-5-105929-6.

44. Council Directive of 12 June 1986 on the Protection of the Environment, and in Particular of the Soil, When Sewage Sludge Is Used in Agriculture (86/278/EEC). EUR-Lex: Luxembourg, 2018. Available online: http:/ / data.europa.eu/eli/dir/1986/278/2 018-07-04 (accessed on 7 October 2021).

45. Tomócsik, A.; Makádi, M.; Orosz, V.; Aranyos, T.; Demeter, I.; Mészáros, J.; Füleky, G. Effect of sewage sludge compost treatment on crop yield. AGROFOR 2016, 1. [CrossRef]

46. Elsalam, H.; Sharnouby, M.E.; Mohamed, A.; Raafat, B.; El-Gamal, E. Effect of Sewage Sludge Compost Usage on Corn and Faba Bean Growth, Carbon and Nitrogen Forms in Plants and Soil. Agronomy 2021, 11, 628. [CrossRef]

47. Eid, E.M.; Alamri, S.A.; Shaltout, K.H.; Galal, T.M.; Ahmed, M.T.; Brima, E.I.; Sewelam, N. A sustainable food security approach: Controlled land application of sewage sludge recirculates nutrients to agricultural soils and enhances crop productivity. Food Energy Secur. 2020, 9. [CrossRef]

48. Meena, M.; Narjary, B.; Sheoran, P.; Jat, H.; Joshi, P.; Chinchmalatpure, A.; Yadav, G.; Yadav, R. Changes of phosphorus fractions in saline soil amended with municipal solid waste compost and mineral fertilizers in a mustard-pearl millet cropping system. CATENA 2018, 160, 32-40. [CrossRef] 